\title{
EFFECTIVENESS OF Betta splendens AS A BIOLOGICAL PREDATORY AGAINST Aedes aegypti LARVAE
}

\author{
Saniya Hanum Permata ${ }^{1}$, Subagyo Yotopranoto ${ }^{2}$, Kusmartisnawati ${ }^{2}$ \\ ${ }^{1}$ Medical Doctor Study Program, ${ }^{2}$ Department of Medical Parasitology \\ Faculty of Medicine, Universitas Airlangga, Surabaya
}

\begin{abstract}
ABSTRAK
Demam Berdarah Dengue (DBD) disebabkan oleh virus dengue yang ditularkan oleh nyamuk Aedes aegypti. Ada beberapa jenis ikan yang diketahui dapat digunakan sebagai predator biologis larva Aedes aegypti, diantaranya ikan cupang (Betta splendens). Tujuan dari penelitian ini adalah untuk menentukan efektivitas spesies Betta splendens sebagai predator biologis larva Aedes aegypti. Larva yang digunakan adalah larva Aedes aegypti pada tahap keempat. Betta splendens yang digunakan terdiri dari empat kelompok replikasi, yaitu: kelompok spesies jantan usia 3 dan 6 bulan, dan kelompok spesies betina usia 3 dan 6 bulan. Tingkat efektivitas predasi hanya dihitung berdasarkan kecepatan makan 25 larva dalam akuarium berisi 3 liter air. Statistik menggunakan metode Annova dengan parameter berat badan ikan dan waktu untuk memangsa. Waktu memangsa terlama dimiliki oleh kelompok spesies jantan usia 3 bulan (memiliki rata-rata berat badan =1,474 gram), dengan waktu rata-rata memangsa $=153,80$ detik. Waktu memangsa terpendek dimiliki oleh kelompok spesies betina usia 6 bulan (memiliki rata-rata berat badan = 2,566 gram ), dengan waktu rata-rata memangsa =142,41 detik. Simpulan, kelompok spesies betina usia 6 dengan rata-rata berat badan tertinggi paling efektif memangsa larva Aedes aegypti. Berat badan dapat mempengaruhi kecepatan memangsa, tetapi berat badan hanya salah satu variabel yang mempengaruhi kecepatan dan efektivitas disamping jenis kelamin dan usia Betta splendens. (FMI 2015;51:268-271)
\end{abstract}

Kata kunci: ikan cupang, larva Aedes aegypti, efektivitas, pemangsa, berat tubuh

\begin{abstract}
Dengue Hemorrhagic Fever (DHF) is caused by dengue virus and transmitted by Aedes aegypti mosquito. There are several fish species known to be used as a biological predator of Aedes aegypti larvae, such as Betta splendens. The purpose of this study was to examine Betta splendens as a biological predator of Aedes aegypti larvae. The larvae used were in the fourth stage. The Betta splendens consisted of four replicate groups, 3 and 6 months male age group, and 3 and 6 months female age group. The effectiveness rate of predation was only counted based on the speed of eating of 25 larvae in the aquarium containing 3 liters of water. Statistical test was performed with Annova with the parameters fish body weight and time to prey. The longest mean of preying time was found in 3 months aged male fish group (mean body weight $=1.474$ grams), with a mean time of prey $=153.80$ seconds. The shortest mean preying time was found ini 6 months aged female fish group (mean body weight $=2.566$ grams), with a mean time of prey $=142.41$ seconds. In conclusion, female 6 month-aged fish with highest mean body weight is most effective againts Aedes aegypti larvae. The body weight can affect the speed of preying, but body weight is only one of some variables that affect the speed and effectiveness beside gender and age of Betta splendens. (FMI 2015;51:268-271)
\end{abstract}

Keywords: Betta splendens, Aedes aegypti larvae, effectiveness, predator, body weight

Correspondence: Saniya Hanum Permata, Medical Doctor Program, Faculty of Medicine, Universitas Airlangga, J1 Prof dr Moestopo 47, Surabaya 60286, Indonesia.

\section{INTRODUCTION}

Dengue Hemorrhagic Fever (DHF) is an arthopod-borne viral disease, a disease caused by a virus and transmitted by insects, in this case mosquitos (Djunaedi 2006). In Indonesia, incidences of DHF is also quite high, in 2007 case fatality rate (CFR) or the percentage of people who died among those who experienced is $1 \%$ with Incidence Rate (IR) 71.78/100,000 population and in 2008 the CFR decreased to $0.86 \%$ with IR 60.02/ 100,000 population (Depkes RI 2009). In the recent decades, it is still not found any vaccine for the prevention of dengue virus diseases transmission, especially DHF. This condition leads preventive methods were more being used. That method aimed to eradicate the Aedes aegypti vectors as major effort to break the transmission chain. The used of chemical insectisides like fogging and repellent left residue limit that still exist in the body and can cause toxicity to humans and other living beings.

Djunaedi reported that to eradicate mosquito vectors can be done by using other biological organism like mosquito larvae predators. The use of predatory 
intention is to use other creatures that potentially prey on the larvae, ie: Betta fish (Betta splendens), tilapia, maanvis ornamental fish (Pterophyllum altum), cere fish, and catfish. From datas above, researchers are interested to explore Betta splendens fish that easily found in Indonesia as biological predator and also this species is known as cleaner because its ability to eat feces.

Betta splendens fish that was choosen, reportedly quite effective on prey Aedes aegypti larvae even though the size is the smallest among other fishes mentioned above. In the present study, researchers will examine the ability of different age groups and different sexes of Betta splendens species as biological predators of Aedes aegypti larvae.

\section{MATERIALS AND METHODS}

This was a true-experimental study with post half control group design done from Juny 2011-January 2012 in entomology laboratory Institute of Tropical Disease of Airlangga University Surabaya to observed the effectiveness of Betta splendens fish as biologic predator of Aedes aegypti larvae. Aedes aegypti larvae at fourth instar age were choosen because they were more easily to separated. Aedes aegypti larvae obtained from Entomology Laboratory Institute of Tropical Disease Universitas Airlangga Surabaya by seeding. Betta splendens were divided into 4 group. They were: 3 months male age group, 6 months male age group, 3 months female age group, and 6 months female age group. Because Aedes aegypti had 6 replication and each group need 25 larvae total larvae needed were 700 . Therefore, total Betta splendens fish needed is 24 fishes.

Time to prey 25 Aedes aegypti larvae in aquarium with 3 liter of water and Betta splendens weight used as research parameters. Aquarium had $30 \mathrm{~cm}$ size of length, $20 \mathrm{~cm}$ size of width, and $10 \mathrm{~cm}$ size of height, so the total volume is 6000 or 6 liter. Net is used to remove fishes and pipette had main function to count beforeafter treatment amount of larvae. Betta splendens body weight datas conducted by digital scale and to know time used to prey using stopwatch.

Research procedure started with placed 25 Aedes aegypti larvae in the aquarium, then added a Betta splendens fish accorded teratment group using net, and also started the stopwatch. Control group also filled with 25 population sample of Aedes aegypti larvae but did not added any biologic predator, while other group added a Betta splendens with age criteria followed. Then, datas collected analyzed statistically descriptive using Analysis of Varience (Anova) method and processed used Windows Software SPSS 17.

\section{RESULTS}

In this research, data taken were body weight of Betta splendens and time needed to prey. Based on datas taken, each group showed results below:

Table 1 . Weight and time to prey on male 6 months age group

\begin{tabular}{ccc}
\hline \multicolumn{3}{c}{ Male 6 Months Age } \\
\hline No. & Weight $(\mathrm{g})$ & Time to Prey $(\mathrm{s})$ \\
\hline 1 & 1.828 & 145.32 \\
2 & 1.848 & 140.50 \\
3 & 1.857 & 149.86 \\
4 & 1.887 & 154.45 \\
5 & 1.927 & 145.52 \\
6 & 1.992 & 155.49 \\
\hline Total & 11.339 & 891.12 \\
\hline Mean & 1.890 & 148.52 \\
\hline
\end{tabular}

Table 2. Weight and time to prey on female 6 months age group

\begin{tabular}{ccc}
\hline \multicolumn{3}{c}{ Female 6 Months } \\
\hline No. & Weight $(\mathrm{g})$ & Time to Prey $(\mathrm{s})$ \\
\hline 1 & 2.483 & 143.56 \\
2 & 2.520 & 140.25 \\
3 & 2.560 & 144.78 \\
4 & 2.573 & 140.80 \\
5 & 2.591 & 145.14 \\
6 & 2.666 & 139.96 \\
\hline Total & 15.393 & 854.46 \\
\hline Mean & 2.566 & 142.41 \\
\hline
\end{tabular}

Table 3. Weight and time to prey on male 3 months age group

\begin{tabular}{ccc}
\hline \multicolumn{3}{c}{ Male 3 Months Age } \\
\hline No. & Weight $(\mathrm{g})$ & Time to Prey $(\mathrm{s})$ \\
\hline 1 & 1.407 & 158.06 \\
2 & 1.416 & 155.16 \\
3 & 1.460 & 147.81 \\
4 & 1.468 & 154.67 \\
5 & 1.571 & 150.58 \\
6 & 1.523 & 156.55 \\
\hline Total & 8.845 & 952.8 \\
\hline Mean & 1.474 & 153.80 \\
\hline
\end{tabular}


Table 4. Weight and time to prey on male 3 months age group

\begin{tabular}{ccc}
\hline \multicolumn{3}{c}{ Female 3 Months Age } \\
\hline No. & Weight $(\mathrm{g})$ & Time to Prey $(\mathrm{s})$ \\
\hline 1 & 1.645 & 158.38 \\
2 & 1.662 & 154.39 \\
3 & 1.677 & 154.87 \\
4 & 1.768 & 148.83 \\
5 & 1.801 & 147.14 \\
6 & 1.809 & 141.12 \\
\hline Total & 10.362 & 893.28 \\
\hline Mean & 1.727 & 148.88 \\
\hline
\end{tabular}

From the results above, significance values (p) on distribution tests from weight body fishes conducted were 0.962 on male 6 months age group; 0.993on female 6 months age group; 0.962 on male 3 months age group; and 0.841 on female 3 months age group. While Significance values (p) on distribution tests from time needed to prey of fishes conducted were 0.974 on male 6 months age group; 0.834 on female 6 months age group; 0.829 on male 3 months age group; and 0.941 on female 3 months age group.

All normal distribution values have significance values less than $\alpha$, and $\alpha$ was 0.05 , so that means that the results of research normally distributed. Those result fulfilled the rules to do Anova Test. Significance values (p) of homogeneity test all varian from weight body parameter was 0.653 and $(\mathrm{p})$ of time needed to prey was 0.088 . The values that more than $\alpha(\alpha=0.05)$ means that datas varian were homogeny. It was also fulfilled the rules to do Anova Test. From Anova test conducted, researchers found it has similar result as early hypothesis $(\mathrm{p}<0.05)$. So, it must be continued to LSD test. From LSD parameter table of fishes body weight showed (p) among all group less than 0.05, so statistically, there was mean differences among body weight of all groups

On male 6 months age and female 6 months age; there was significant difference $(0.041<0.05)$. Statistically, female 6 months age needed shorter time to prey than male 6 months age. It also means that female 6 months age were more effective than male 6 months age. Whereas on male 6 months age and male 3 months age; there was no significant difference $(0.074>0.05)$. Statistically, male 6 months age needed longer time to prey than male 3 months age. It also means that male 3 months age were more effective than male 6 months age. Then on male 6 months age and female 3 months age; there was no significant difference $(0.427>0.05)$. Statistically, male 6 months age needed longer time to prey than female 3 months age. It also means that female 3 months age were more effective than male 6 months age.

On female 6 months age and male 3 months age; there was significant difference $(0.001<0.05)$. Statistically, Female 6 months age needed shorter time to prey than male 3 months age. It also means that female 6 months age were more effective than male 3 months age. While on female 6 months age and female 3 months age; there was significant difference $(0.004<0.05)$. Statistically, Female 6 months age needed shorter time to prey than female 3 months age. It also means that female 6 months age were more effective than female 3 months age.

Last on male 3 months age and female 3 months age; there was no significant difference $(0.294>0.05)$. Statistically, male 3 months age needed longer time to prey than female 3 months age. It also means that female 3 months age were more effective than male 3 months age. From LSD test conducted that only female 6 months age group that had significant time difference.

Time needed to prey larvae, not influenced much on fishes body weight in a group. It proved by random distribution and it was not a must that heavier fishes had significant diference with the lighter in a replication group. But female 6 months age group had significant body weight difference among others. Reasearchers concluded that body weight not influenced time needed to prey larvae, but body weight only a variable that influenced together with sex and age of fishes.

\section{DISCUSSION}

From previous studies it is known that Betta splendens females have higher agressivity especially in finding prey (Todd et al 2008). Pamplona et al (2009) of Brazil has also conducted research on fish larvae predators. From these studies as many as 369,000 larvae of Aedes aegypti had been eaten by 6 different species of fish. Females Betta splendens are used as control. In these experiments female fish Betta splendens can consume up to 500 larvae per day and has a mortality rate of less than $3 \%$ during the trial period. Furthermore it is concluded that male and female Trichogaster trichopteros; males Astyanax fasciatus; females Betta splendens and Poecilia sphenops proved as the most effective predators of Aedes aegypti larvae.

It can be concluded almost all fish have the power larvasidal but not all are suitable when placed in the bath abate household as a substitute due to several fish size, too large and produce a lot of dirt and other foods besides larvae need to make ends meet. 
Nam et al (2000) of Vietnam mention, not only fish but can also use Mesocyclops (Copepoda) as biologic predator and Micronecta (Corixidae) as a biological control against Aedes aegypti larvae . Lately, it has been widely known that some mosquito larvae have been resistant to the use of temephos/abate of eight rural area in Brazil four areas have mosquito larvae resistant abate (Pamplona et al 2009), so the use of predators for Aedes aegypti mosquito larvae very important to because it low prices and not give much damages to environment.

From the above framework and datas obtained by the researcher, level of effectiveness of betta fish Betta splendens as biological prdator Aedes aegypti larvae can be used as an attempt to control Aedes aegypti larvae safer, faster, economical, and effective and also can be applied in the wider community. The effective use of this fish is expected could decrease the number of DHF (Dengue Hemoraghic Fever) patients incidences.

\section{CONCLUSION}

Betta splendens of four groups: male 6 months age, female 6 months age, male 3 months age and female 3 months age, have their function to prey Aedes aegypti larvae biologically. Female 6 months age fishes group was more effective in terms of speed to prey against other groups. In this study, a group of fish with an average weight higher have the ability to prey on the larvae faster. Moreover, it can be concluded that it is not always weight can affect the speed of prey fish larvae. It can be concluded weight of the fish is one of the variables that affect the speed and effectiveness in addition to sex and age of the fish

\section{REFERENCES}

Depkes RI (2009). DBD: Insiden dan CFR Indonesia tahun 1968-2008. Available from http://www.penyakit menular.info/webpppl/def_menu.asp?menuldType $=0$ $\&$ Subid=1. Accessed June 6, 2011

Djunaedi D (2006). Demam Berdarah Dengue, Malang, UMMpress

Pamplona Lde G, Alencar CH, Lima JW, Heukelbach J (2009). Reduced oviposition of Aedes aegypti gravid females in domestic containers with predatory fish. Trop Med Int Health 14, 1347-1350

Todd NE, Sica A, Trahey R (2008). Aggression, interactions, and preference for males in female siamese fighting fish (Betta splendens). Journal of Behavioral and Neuroscience Research 6, 15-28

Nam VS, Yen NT, Holynska M, Reid JW, Kay BH (2000). National progress in dengue vector control in Vietnam: survey for Mesocyclops (Copepoda), Micronecta (Corixidae), and fish as biological control agents. Am J Trop Med Hyg 62, 5-10 